存を減らそうと考えているようだが, 新エネルギーの発 電量には限界があり，すべてを補うことは不可能である というのがYGNメンバーの意見であった。このような 事情もあり，原子炉の廃止政策は計画通りに進んでいな いが, 原子炉が新しく建設されない限り, 出力の向上や, 炉寿命を延ばすことしか，原子力技術者にできる方策は ないとのことであった。また, スウェーデンでは, 電気 料金が変動し, 停電も発生するのに対し, 日本の電力供 給は安定しており, 電気料金の変動もほとんどなく, 電 力の輸出入も行われていない。そのため, スウェーデン に比べて日本ではエネルギー問題に国民の関心が薄いの ではないか。このようなエネルギー問題に対する意識の 違いは, スウェーデンでは原子力利用に肯定的な世論で あるのに対し, 日本においては, 原子力は必要であると 考えられているものの，原子力に対するよいイメージを
国民が持っていないといった，原子力利用に対する国民 の意識の違いにも影響しているのではないかという意見 も出された。

\section{4. さいごに}

スウェーデンでは，予算面の支援や特別休㗇の付与な ど，原子力関連企業全体で YGN 活動のバックアップが 行われていることが印象的であった。人口が一千万人に 满たないスウェーデンのような国家に扔いて, 原子力技 術を継承していくためには，次世代を担う若者を原子力 産業界全体で育成していくべきであるという考え方なの であろう。意見交換会を行ったスウェーデンYGNメン バーも，自国の原子力拉よびエネルギー問題について しっかりとした意見を持っていたように思う。

(文責：YGN 運営委員・石寺孝充)

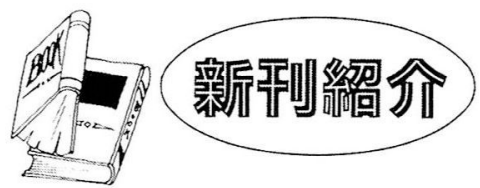

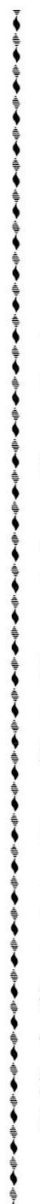
である。

\section{放射線と現代生活 一マリー・キュリーの夢を求めて一} アラン・E・ウォルター著/高木直行・千歳敬子共訳, B 5 判, 315 p. (2006.11.), ERC 出版, (価格1, 900円税別) ISBN4-900622-39-7

ポーランドの首都，ワルシャワ旧市街の城壁を西に抜けた すぐのところに, Maria Skłodowska(後のマリー・キュリー) の生家がある。現在は博物館となっており, 当時の暮らしか ら後の業績までを偲ぶ遺物が展示されている。本書の読了 後, 評者は副題である「マリー・キュリーの夢を求めて (Fulfilling Marie Curie's Dream)」に，正にその「夢」が小さな その家で生まれたことを想い, 改めて深い感慨に浸った次第

本書は，米国原子力界の大家の闊達な筆により，放射線が 現代社会の日常生活の至るところで有効に活用されているこ とを，抻話や事例をふんだんに盛り込みながら平易にかつ詳 細に解説しており，豊富な情報を網羅する教科書でありなが ら酒脱なエッセイの一面をも併せ持つ。本書を手にした読者 は，尽きせ好知識の泉に存分に浸り，遊び，学ぶことができ よう。さらに加えて, キュリー夫妻の孫にあたるエレーヌ・ ランジュヴァンージョリオ博士による序文に, マリー・キュ リーの足跡が簡潔ながら鮮明に綴られ，上述の「夢」の所以を 描写していることが, 本書の魅力をいや増している。正に, 今日われわれが享受している繁栄の多くの部分が，キュリー 夫妻の研究に端を発し，実現した夢のただ中にあることに改 めて思いを致させる書である。

必ずしも本書自身の备ではないが，読み手の自戒としてあ
えて 2 点指摘する。本書は純粋に自然 科学の立場から放射線並びに核科学の 有用性を総説したものであり, 現代社 会に生きる一人ひとりが合理的なりス ク判断と選択をする上で有益な情報を 提供する。しかし，たとえ同じ事物で あっても，自ら積極的に選択するもの かまたは知らされることなく間接的に 選択させられていたものであるか，あ るいはその事物を扱う人・団体への信

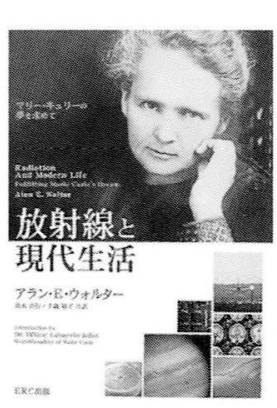
頼の有無などによって，リスクに対する認知は大きく異なる がゆえに，「真実」が常に受け入れられる保証はない。本書が 提示する科学的真実に加えて，そのような「現実」に対するリ スク選択の方法論と, 市民社会による実践の蓄積とが相まっ て，はじめて社会全体として望ましい選択につながっていく のであり，すなわち本書は優れた良書であるがそれのみで万 能とはみるべきでない。なお，このような現実のリスク選択 問題については6.4節, 10.5節などに簡潔に触れられている が, より詳細には前著(『衰退するアメリカ 原子力のジレン マに直面して』日刊工業新聞社)を併読することで，著者の主 張が俯㒈できる。

また，第13章「現代の経済」では，放射線技術が米・日・中 で生み出している経済的便益の評価を紹介しているが，示さ れている結果の数值を見る際には, 売上高の単純集計が過大 評価となる可能性(本来は付加価值を集計すべきであること) や，国際比較における為替レートの設定の難しさなどを念頭 に，慎重な見方をすべきである。

訳出は評者と同世代の気鋭 2 名の手になるもので, どちら かといえば原子炉技術の専門家ゆえ, 農業, 医療などの章で は相当の労苦があったものと推察する。全体を通じて生き生 きとした親しみやすい文体を貫くことに成功しており，賞賛 に值する。 